\title{
Synergistic effect of reduced polypeptide micelle for co-delivery of doxorubicin and TRAIL against drug-resistance in breast cancer
}

\author{
Chuling Hu${ }^{1, *}$, Fenfen $\mathrm{Gu}^{1, *}$, Zongguang Tai ${ }^{1,{ }^{*}}$, Chong $\mathrm{YaO}^{1}$, Chunai Gong ${ }^{1}$, Qingming \\ $\mathrm{Xia}^{1}$, Yuan Gao ${ }^{1}$, Shen Gao ${ }^{1}$ \\ ${ }^{1}$ Department of Pharmaceutics, Changhai Hospital, Second Military Medical University, Shanghai 200433, China \\ *These authors contributed equally to this work \\ Correspondence to: Shen Gao, email: liullk@126.com \\ Yuan Gao, email: gaoy82@hotmail.com
}

Keywords: polyarginine, lipoic acid, reduction-sensitive, drug resistance, cancer therapy

Received: May 02, 2016 Accepted: August 13, $2016 \quad$ Published: August 20, 2016

\section{ABSTRACT}

Cationic peptides as a non-viral gene vector have become a hotspot of research because of their high transfection efficcacy and safety. Based on our previous study, we synthesized a cationic reduction-responsive vector based on disulfide cross-linked L-arginine, L-histidine and lipoic acid (LHRss) as the co-carrier of both doxorubicin (DOX) and the necrosis factor-related apoptosis-inducing ligand (pTRAIL). The LHRss/DOX/TRAIL construct has reduction-sensitive behavior and an enhanced endosomal escape ability to increase the cytotoxicity of DOX and the transfection efficiency. Further, the LHRss/DOX/TRAIL construct increased the accumulation of DOX and promoted the expression of PTRAIL, thus increasing cellular apoptosis by $83.7 \%$ in MCF-7/ADR cells. In addition, the in vivo biodistribution results showed that the LHRss/DOX/TRAIL construct could target tumors well. The in vivo anti-tumor effect study demonstrated that the LHRss/DOX/TRAIL construct inhibited tumor growth markedly, with a tumor inhibitory rate of $\mathbf{9 4 . 0 \%}$. The co-delivery system showed a significant synergistic anti-tumor effect. The LHRss/DOX/TRAIL construct may prove to be a promising co-delivery vector for the effective treatment of drug resistant breast cancer.

\section{INTRODUCTION}

Multidrug resistance (MDR) often leads to failure of breast cancer chemotherapy because MDR may increase cell surface drug-pump protein efflux, inhibit cancer cell apoptosis, decrease drug influx, and alter cell cycle regulation $[1,2]$. Tumor cells are characterized by a strong proliferative ability, but the most important feature of tumor cells is their loss of the ability to undergo spontaneous apoptosis. Thus, the study of apoptosis in tumors is one of the more promising breakthrough points in tumor chemotherapy [3]. It was reported that tumor necrosis factors (TNF) such as TNF- $\alpha$ can increase tumor cell apoptosis and enhance the efficacy of chemotherapy drugs [4]. TNF-related apoptosis-inducing ligand (TRAIL) has recently been identified as a protein of interest because of its remarkable ability to induce rapid apoptosis of tumor cells without affecting most normal cells. TRAIL induces apoptosis by interacting with death receptor 4 (DR4) and death receptor 5 (DR5), leading to the formation of the death-inducing signaling complex (DISC), which binds caspase- $8[4,5]$. The recruitment of caspase- 8 to the DISC activates its proteolytic properties, thus initiating a cascade of protease activation involving enzymes such as caspase-3, which promotes the subsequent cleavage of death substrates and results in apoptosis. Herein, codelivery TRAIL and chemotherapeutic drugs may increase the synergistic effects of drug efficacy and prohibit the MDR of chemotherapy. However there are challenges of the transport of chemotherapeutic drugs and gene drugs in the co-delivery systems such as ineffective cellular transfection, instability in vivo of gene drug, as well as non specific target effect of drugs $[6,7]$.

Effective delivery systems can cross various barriers in vivo and intracellularly deliver drugs to the target tumor cells and cause an antitumor effect $[8,9]$. 
Therefore, these delivery systems should have multiple functions such as long-term stability, target specificity, and the ability to enhance endosomal escape [10]. The synthesis of functional units, a technology using supramolecular groups to assemble multiple functional units into a combination, is an effective method to obtain multi-functional carriers. The ordered structure of selfassembly with the appropriate nano-size and a controllable structure that can cross a series of barriers, such as the cell membrane, the endosomal membrane, and the nuclear membrane, has great potential prospect [11].

In this study, we developed a nanosystem based on disulfide cross-linked lipoic acid modified polyarginine peptide and histidine (LHRss) for co-delivery of the chemotherapeutic drug doxorubicin (DOX) and TRAIL to MDR breast cancer cells. Polyarginine, as a cell penetrating peptide, was used as an intracellular delivery vector, knowing that it can effectively compress DNA by enriching the positive charges in the DNA $[12,13]$, and histidine can help nanomicelle endosomal escape through the proton sponge effect $[14,15]$. Moreover, the intermolecular disulfide bonds of lipoic acid can avoid instability by self-assembling into a nanomicelle in vivo that is cracked in the glutathione-reducing conditions in tumor cells, releasing the drug and avoiding the failure of effective drug release in cells $[16,17]$. The LHRss/DOX/ TRAIL construct was assembled into a nanomicelle structure with DOX encapsulated in the hudrophobic core and pTRAIL condensed on the hudrophilic layer. We hypothesized that the LHRss/DOX/TRAIL construct could effectively enhance the cytotoxicity of the drug, promote the apoptotic response, providing a targeted delivery and enhanced effect of DOX and TRAIL to drug-resistant breast cancer cells (Figure 9). For this purpose, cellular uptake, in vitro transfection efficiency, cytotoxicity, cellular apoptosis rate, in vivo distribution as well as antitumor effect of the LHRss/DOX/TRAIL construct were investigated in a drug-resistant breast cancer xenograft nude mice model.

\section{RESULTS AND DISCUSSION}

\section{Characterization of LHRss}

LHR was synthesized using F-moc-SPPS, and cysteine was used as a cross-linking agent to cross-link an intermolecular disulfide bond of lipoic acid to obtain the appropriate molecular weight for further research. At the same time, methanol was used as a solvent. After completion of the reaction, the solvent was removed by $\mathrm{N}_{2}$ drying, and the remaining cysteine was neutralized by $\mathrm{NaOH}$. The peptide LHR was synthesized with $>95 \%$ purity and a precise molecular weight of 1554.88 $\mathrm{Da}$. The mass-average molecular weights $(\mathrm{Mw})$ of the polymers are summarized in Table 1 . The $\mathrm{Mw}$ of the LHRss was $22.9 \mathrm{kDa}$ when the molar ratio of cysteine to LHR was $10 \%$, and the Mw of the LHRss was significantly enhanced compared to that of the original monomer LHR (1544.88 Da). The formation of LHRss was verified by ${ }^{1} \mathrm{H}-\mathrm{NMR}$ (Figure 1B). Figure 1B shows the ${ }^{1} \mathrm{H}$ NMR results of LHRss, indicating that $\delta 3.59 \mathrm{ppm}$ (signal c) belonged to the methyne of the lipoic acid, and $\delta 2.34 \mathrm{ppm}$ (signal $\mathrm{g}$ ) belonged to the hydrogen on the methylene group of the carbonyl group. $\delta 3.48 \mathrm{ppm}$, $2.58 \mathrm{ppm}$ and $\delta 1.36 \sim 1.59 \mathrm{ppm}$ were from the proton of lipoic acid moiety (signals a,b,e,d and f, respectively). The peak at $\delta 1.79 \mathrm{ppm}$ (signal i) and the peak at $\delta 2.04 \mathrm{ppm}$ were attributed to $-\mathrm{CH} 2-$ close to the tertiary carbon in arginine and histidine (signal $\mathrm{m})$. Signals $\mathrm{d}(\delta 1.54 \mathrm{ppm})$ and $\mathrm{h}(\delta 3.19 \mathrm{ppm})$ were attributed to the rest of $-\mathrm{CH} 2-$ in arginine. The peaks at $\delta 4.23-4.62 \mathrm{ppm}($ signal $\mathrm{n}$ ) were due to protons of tertiary carbon in the polymer. The peak at $\delta 7.17 \mathrm{ppm}$ (signal $\mathrm{j}$ ) and $\delta 8.54 \mathrm{ppm}$ (signal k) were from protons of imidazole in histidine.

\section{Characterization of LHRss/DOX/pGL3 complexes}

The zeta potential and particle size of LHRss/DOX/ DNA are closely related to the N/P ratio. The LHRss/ DOX/pGL3 complexes were prepared at different N/P ratios from 2.5:1 to 80:1. As shown in Figure 2A, all complexes had a positive surface charge with a zeta potential ranging from 10 to $30 \mathrm{mV}$ when the $\mathrm{N} / \mathrm{P}$ ratio was higher than 10. Figure $2 \mathrm{~A}$ also shows that the particle size of the LHRss/DOX/pGL3 complexes was less than $200 \mathrm{~nm}$ at all the N/P ratios. When the N/P ratio was higher than 10, most LHRss/DOX/pGL3 complexes had a higher zeta potential and a smaller particle size than the low N/P ratio complexes. Among the LHRss, LHRss/ $\mathrm{DOX} / \mathrm{pGL} 3$ was found to have an appropriate size and zeta potential (Figure 2B and 2C) at an N/P ratio at 40, with a particle size and zeta potential of $69 \pm 2.14 \mathrm{~nm}$ and $30.7 \pm 2.94 \mathrm{mV}$, respectively. TEM showed that the LHRss/ DOX/pGL3 complexes formed a compact nanostructure, with a similar size as the results shown in Figure 2D at an $\mathrm{N} / \mathrm{P}$ of 40 . Figure $2 \mathrm{E}$ showed that with different N/P ratios from 0.25 to 15 , the condensing ability of LHRss was enhanced as the N/P ratio was increased. When the N/P ratio was greater than 5 , the pGL3 plasmid was completely condensed, indicating that the compression ability of LHR was improved by cross-linking with the disulfide bond. To confirm this finding, DTT, a reducing agent, was used to break the disulfide bond. As shown in Figure 2E, the LHRss/DOX/pGL3 complexes showed a weaker pGL3 binding affinity in the presence of DTT because of the depolymerization of LHRss. Thus, we presume that the inter-molecular disulfide bond of lipoic acid can be broken by reducing the condition in the cytoplasm, thus reducing the affinity of LHRss for pGL3. The characteristics of the inter-molecular disulfide bond of lipoic acid remain stable extracellularly but not stable in the cytoplasm, which 
Table 1: The synthetic conditions and the corresponding molecular weight of LHRss

\begin{tabular}{lcccc}
\hline \multicolumn{1}{c}{ Polymers } & LHR(mg) & Cysteine(mg) & Feed ratio(\%) $^{\mathrm{a}}$ & Mw(kDa) $^{\mathrm{b}}$ \\
\hline LHR & - & - & - & 1.555 \\
LHRss & 50 & 0.39 & 10.0 & 22.9 \\
\hline
\end{tabular}

Notes: ${ }^{a}$ Molar ratio of cysteine to LHR. ${ }^{b}$ Data obtained by gel permeation chromatography.

can provide a guarantee for the effective uptake and the effective release of the drug.

\section{Loading and release at different pHs of DOX}

Loading of DOX into LHRss/DOX/TRAIL was performed by Dialysis method. It was found that the DLC was $12.5 \%$ wt, and the DLE was as high as $71.4 \%$. DOX released from the micelles was $\mathrm{pH}$-sensitive, as shown by the experiments carried out under two different $\mathrm{pH}$ conditions ( $\mathrm{pH} 5.5$ and 7.4) (Figure 2F). Through the spontaneous fluorescence behavior of DOX, the content of DOX can be detected. The drug release behavior was detected by dialysis. Thus, if DOX was completely condensed in the LHRss, only the released DOX could be detected. The cumulative release rate increased with the lower $\mathrm{pH}$ of the release media, from $54.5 \%$ in $\mathrm{pH} 7.4$ medium to $95.5 \%$ with $60 \mathrm{~h}$ in the media with $\mathrm{pH}$ of 5.5 , which is most likely due to the release of the drug from the disulfide bond under acidic conditions. It was reported that the glutathione concentration in the cytosol of tumor cells was 100-1,000 times that of normal cells [18]. Kim et al. [19] reported that the disulfide bond could be cleaved rapidly via thiol-disulfide exchange reactions with intracellular reducing molecules, especially glutathione. Our study showed that the prepared nanomicelle could rapidly release drugs under the reducing conditions of tumor cells.

\section{Cellular uptake}

Cellular uptake is an important factor in drug delivery. To determine the cellular uptake of LHRss and the cellular DNA uptake mediated by LHRss/pDNA, the LHR/pDNA in MCF-7 cells and MCF-7/ADR cells was measured using YOYO-1 labeled pDNA. The positive cells were quantitatively assessed by flow cytometry after being incubated for 1, 2, and $4 \mathrm{~h}$. As shown in Figure $3 \mathrm{~A}$, the fluorescent signal could not be detected in cells treated with LHR/ YOYO-1pDNA, even after being
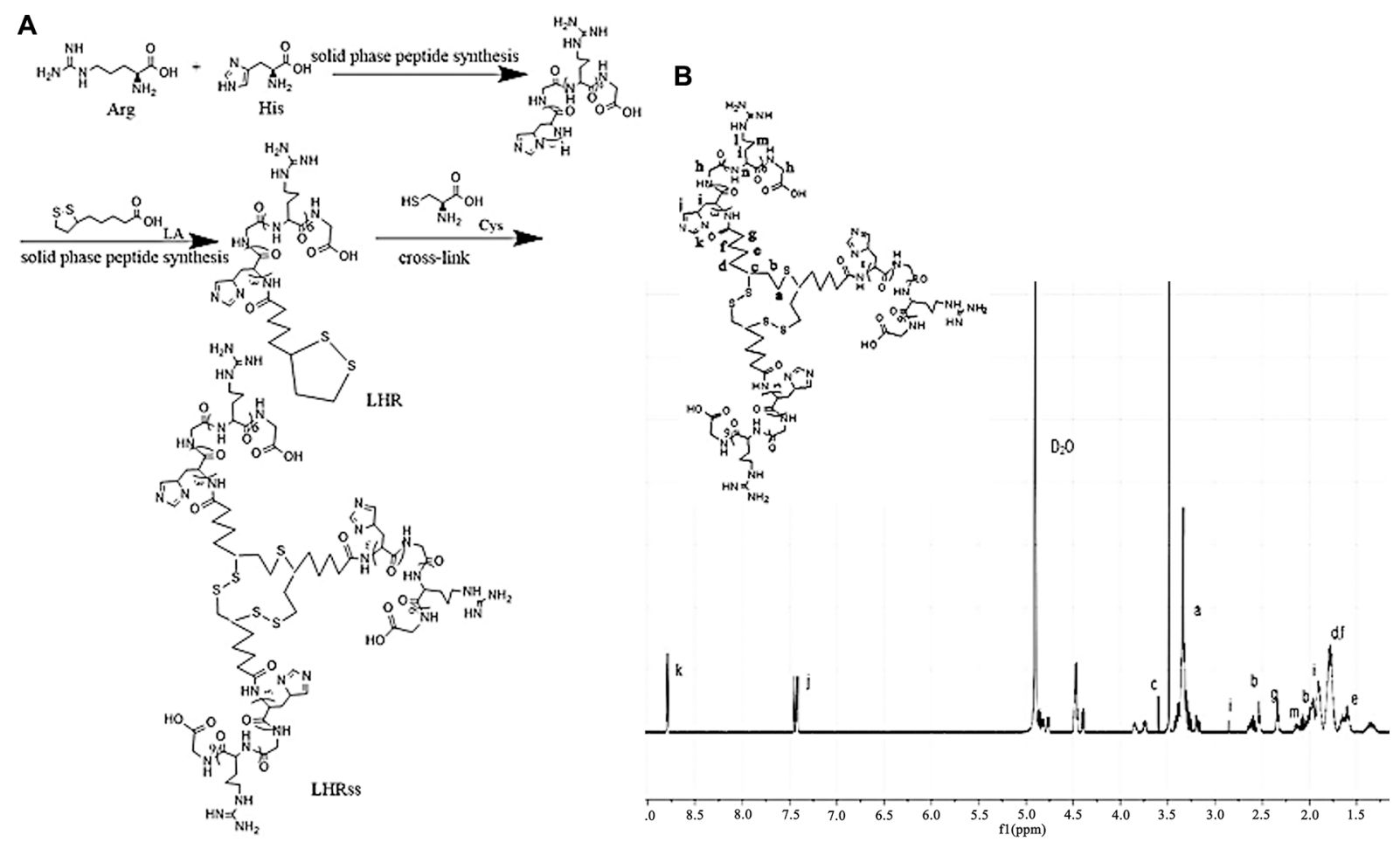

Figure 1: Synthesis and ${ }^{1}$ H-NMR determination of LHRss (A) Synthesis of LHRss and (B) ${ }^{1}$ H-NMR spectra of LHRss in $\mathrm{D}_{2} \mathrm{O}$ at $600 \mathrm{MHz}$. Abbreviations: Arg, arginine; His, histidine; LA,L-lipoic acid; cys, cysteine; LHR, lipoic acid modified polyarginine peptide and histidine (LHRss); LHRss, disulfide cross-linked lipoic modified with polyarginine peptide and histidine. 
incubated for $4 \mathrm{~h}$, probably because of the low positive charge of the micelles compressing the DNA and its low affinity to the cell membrane. The cellular uptake of LHRss/ YOYO-1pDNA by MCF-7 cells and MCF-7/ ADR cells was time-independent. The uptake of pDNA by MCF-7/ADR cells was slightly more than the uptake by MCF-7 cells. The cellular uptake results showed that the cellular uptake efficiency of the LHRss/pDNA nanomicelle was significantly higher than that of the LHR/pDNA in both MCF-7 and MCF-7/ADR cells. The amount of positive cells was approximately 9.59 fold and 21.05 fold that of the LHR/pDNA nanomicelle in MCF-7 and $\mathrm{MCF}-7 / \mathrm{ADR}$ cells, respectively, probably because cross-linking increased the affinity of the nanocarrier with the cell membrane [20].

Figure 3B shows the uptake of free DOX and LHRss/ DOX by MCF-7 and MCF-7/ADR cells. In MCF-7 cells,
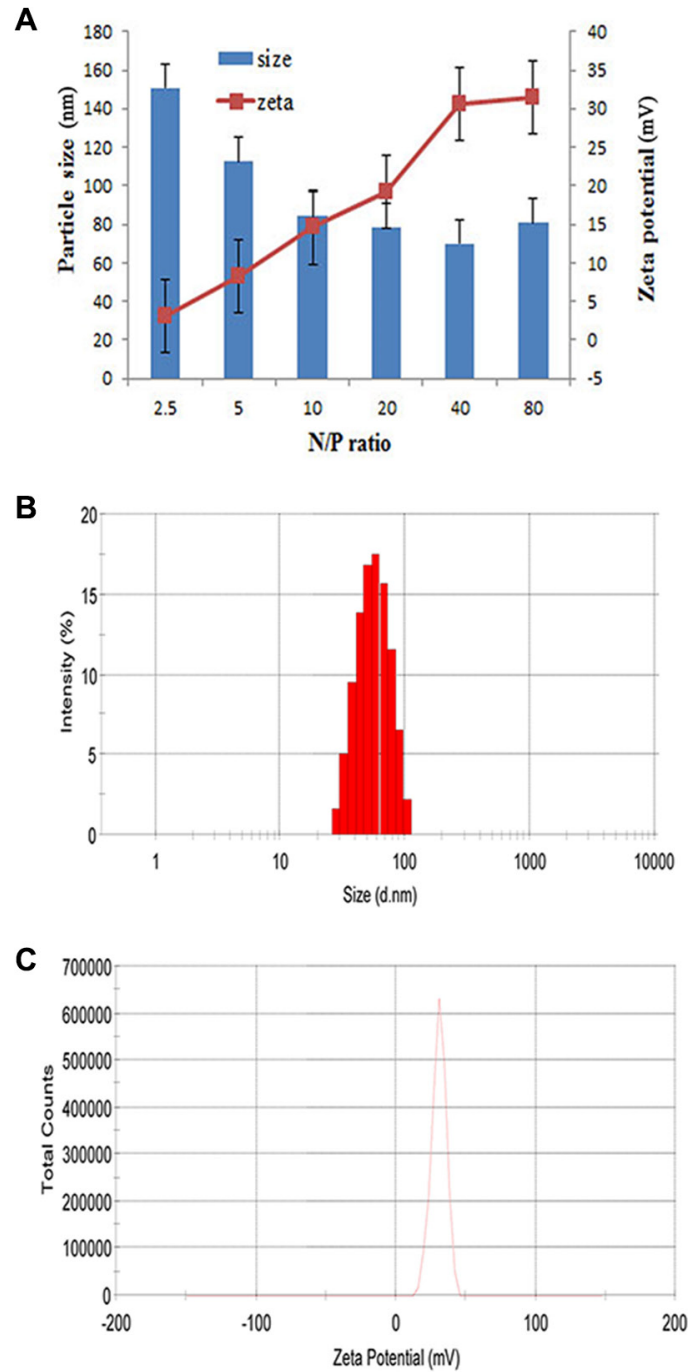

the cellular uptake of free DOX and LHRss /DOX was both high, and almost saturated at $2 \mathrm{~h}$. However, the uptake of free DOX in MCF-7/ADR cells was low, while the LHRss/DOX had a high accumulation after 4-h treatment, indicating that the uptake might be derived from caveolae endocytosis or micropinocytosis [21]. The high expression of $\mathrm{p}$-gp in the drug resistant cells would efflux DOX, which entered the membrane through electrostatic interaction [22]. However, the micelles could enter the cells through clathrin- or caveolin-mediated endocytosis and bypass the drug efflux pumps, thus increasing the cellular uptake.

To observe the intracellular location of LHRss/ YOYO-1pDNA, DOX, LHRss/DOX, and LHRss/DOX/ YOYO-1pDNA, DAPI (4',6-diamidino-2-phenylindole) was used to stain the nucleus. Figure $3 \mathrm{Ca}$ shows the intracellular distribution of the micelle in MCF-7 and

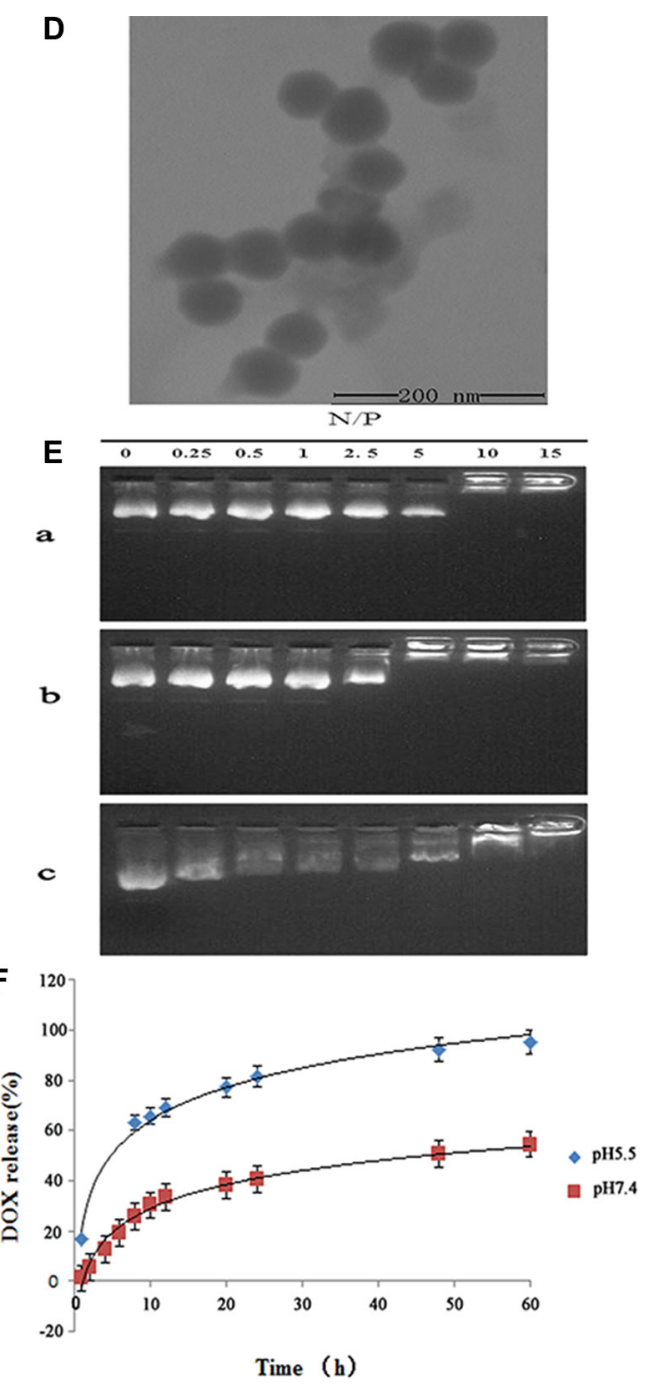

Figure 2: Characterization ofLHRss/DOX/TRAIL. (A) Particle size and zeta potential of LHRss/DOX/TRAIL determined by DLS. (B) Particle sizes distribution of LHRss/DOX/TRAIL at N/P ratio of 40 determined by DLS. (C) Zeta potential of LHRss/DOX/ TRAIL at N/P ratio of 40 determined by DLS. (D) TEM images of LHRss/DOX/TRAIL at mass ratio at N/P ratio of 40. (E) Agarose gel electrophoresis results (a. agarose gel electrophoresis of LHR/pGL3; b. agarose gel electrophoresis of LHRss/pGL3; c. agarose gel electrophoresis of LHRss/pGL3 at DTT condition). (F) Release of DOX from LHRss/DOX/TRAIL. 
MCF-7/ADR cells $4 \mathrm{~h}$ after transfection. The confocal microscopic images of MCF-7 and MCF-7/ADR cells showed a large amount of green fluorescence in the cytoplasm and a small punctate in the nucleus, which coincided with blue fluorescence, indicating that YOYO1-labeled pDNA successfully escaped from the endosome and entered the nucleus [23, 24]. These results showed that the LHRss could promote endosomal escape. Figure $3 \mathrm{Cb}$ and Figure $3 \mathrm{Cc}$ showed the intracellular location of free DOX and LHRss/DOX in MCF-7 and MCF-7/ADR cells. The location of free DOX was basically the same as the LHRss/DOX, indicating that the drug DOX could enter the nucleus to play the cytotoxic effect. While in MCF-7/ADR cells, only a small amount of free DOX was distributed in the cytoplasm and could not enter the nucleus. Interestingly, when MCF-7/ADR cells were treated with LHRss/DOX, the distribution of red fluorescence in the nucleus DOX was significantly increased. The result is consistent with the above cellular uptake. Figure $3 \mathrm{Cd}$ showed the co-delivery system of DOX and pDNA, where the green fluorescence was distributed in both cytoplasm and nucleus in both MCF-7 and MCF-7/ADR cells. The red fluorescence was distributed in the nucleus in both MCF-7 cells and MCF-7/ADR cells. These results suggested that the co-delivery system could carry the gene drug and chemotherapy to the cell nucleus.

\section{Gene transfection efficiency}

The gene transfection efficiency of LHRss was measured using a reporter genes (EGFP) in MCF-7 and MCF-7/ADR cells. It seemed that the gene transfection efficiency was dependent upon the N/P ratio, and this result was observed for both $\mathrm{MCF}-7$ and MCF-7/ADR cells (Figure 4A). The gene transfection efficiency of the LHRss in both MCF-7 and MCF-7/ADR cells at N/P ratio

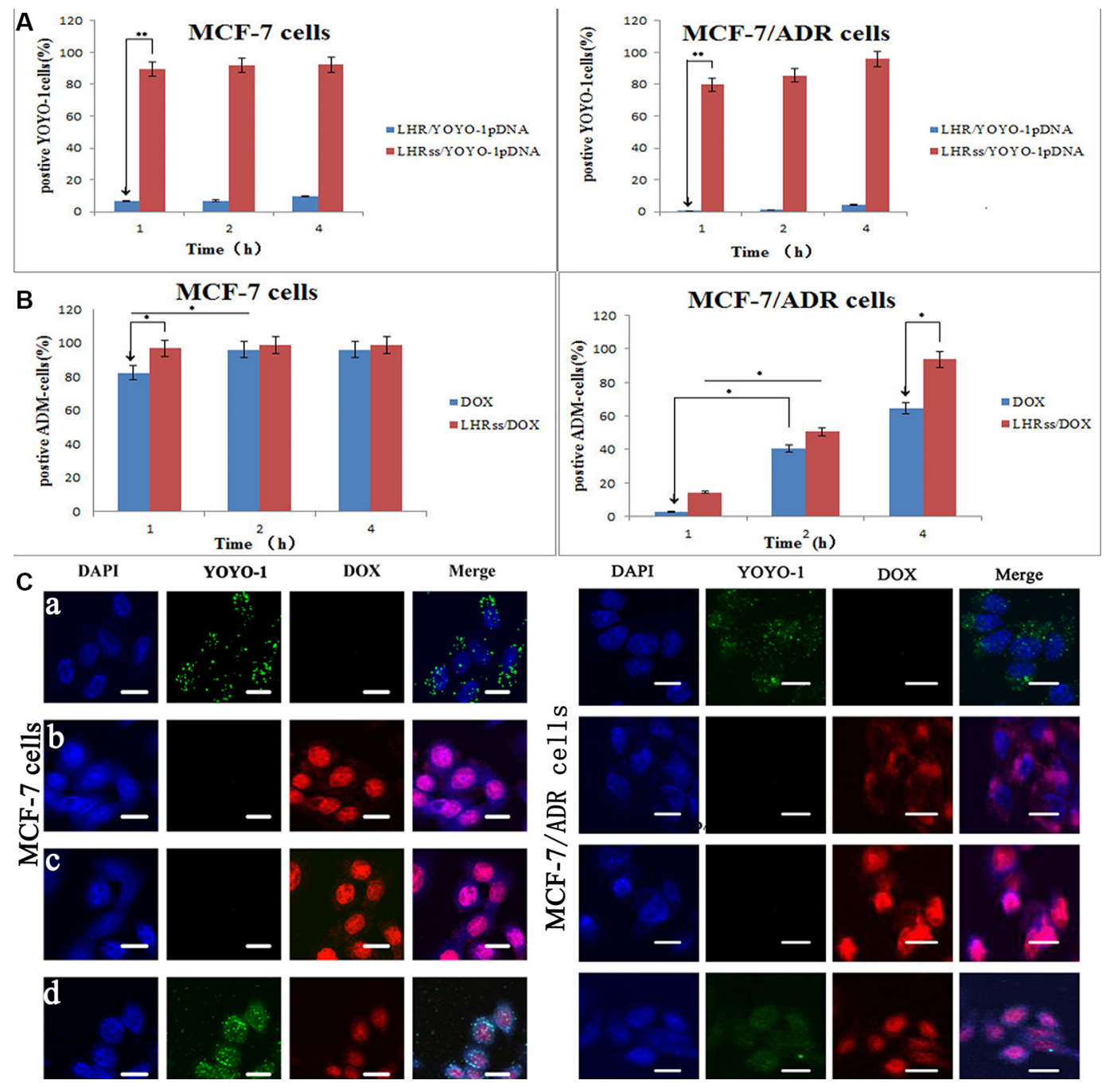

Figure 3: Cellular uptake of DOX and YOYO-1 pDNA. (A) Quantitative analysis uptake of YOYO-1 pDNA in MCF-7 cells and MCF-7/ADR cells after treated with LHR/YOYO-1 pDNA and LHRss/YOYO-1 pDNA for 1, 2 and 4 h. (B) Quantitative analysis of DOX uptake in MCF-7 cells and MCF-7/ADR cells after treated with DOX, LHRss/DOX for 1, 2 and $4 \mathrm{~h}$. (C) Confocal microscopic images of MCF-7 cells and MCF-7/ADR cells incubated with LHRss/YOYO-1 pDNA (a), DOX (b), LHRss/DOX (c) and LHRss/DOX/YOYO-1 pDNA (d). 
40 was significantly higher than that in the groups at N/P ratio $20(p<0.05)$ (Figure $4 \mathrm{~B}$ and $4 \mathrm{C})$, most probably because of the enhanced gene compression of the LHRss [25]. It is noteworthy that LHRss showed the optimal gene transfection efficiency at an N/P ratio of 40 .

\section{Cytotoxicity assay}

A successful co-delivery system requires the minimal toxicity of the blank polymer. Figure 5A showed the cytotoxicity of LHRss. The viability of MCF-7 and MCF-7/ADR cells was not significantly affected at the concentrations of LHRss up to $200 \mu \mathrm{g} / \mathrm{mL}$, indicating that LHRss almost has no cytotoxicity and has a good biocompatibility.

The $\mathrm{IC}_{50}$ value of free DOX in MCF-7 and MCF-7/ ADR cells at $48 \mathrm{~h}$ determined by CCK-8 assay was $2.2 \times 10^{-4}$ and $0.97 \mathrm{mg} / \mathrm{mL}$, respectively, indicating a strong resistance in MCF-7/ADR cells (Figure 5B). LHRss/DOX and LHRss/DOX/TRAIL showed no higher cytotoxicity as compared with free DOX in MCF-7 cells. In MCF-7/ADR cells, LHRss/DOX had an $\mathrm{IC}_{50}$ value of $6 \times 10^{-3} \mathrm{mg} / \mathrm{mL}$, indicating an increased cytotoxicity by 49.1 fold, which may result from TRAIL and the burst release of DOX induced by the acidic $\mathrm{pH}$ of endosomes/lysosomes. The most remarkable killing effect in MDR cells was achieved by LHRss/DOX/TRAIL. The synergy between DOX and TRAIL decreased the $\mathrm{IC}_{50}$ value to $2.50 \times 10^{-3} \mathrm{mg} / \mathrm{mL}$. In addition, LHRss accelerated the intracellular DOX release and improved the endo/lysosomal escape and the release of TRAIL, making the LHRss/DOX/TRAIL an efficient co-delivery system with good synergy between the drugs and DNA, and caused a significantly decline in MDR in vitro.

\section{Cell apoptosis}

Figure 5C showed the apoptosis of MCF-7/ADR cells with each treatment group. MCF-7/ADR cells exposed to BMPs did not show any visible apoptosis after 48-h incubation, which is consistent with the result of CCK-8 assay. Likewise, only $12.73 \%$ of the cells were apoptotic because of treatment with free DOX, which failed to afford clear therapy efficacy due to the efflux effect of P-glycoprotein ( $\mathrm{p}$-gp). There was no obvious therapeutic effect of the single delivery of pTRAIL, distinctly disclosing the synergistic effect on apoptosis induction in the cells. As shown by the flow cytometry images, LHRss/DOX induced $60.19 \%$ cellular apoptosis by benefiting from the up-regulation of TRAIL by LHRss/ TRAIL and the intracellular accumulation of DOX. Nevertheless, LHRss/DOX/TRAIL caused $83.78 \%$ cell apoptosis via the synergist effect of DOX and TRAIL.

\section{Biodistribution}

DIR, a lipophilic fluorescent dye, is a model drug for targeted research of nanomicelles [26, 27]. The distribution of free DIR in each tissue was observed using an in vivo imaging system. As seen in Figure 6, most free
A $\quad 10$

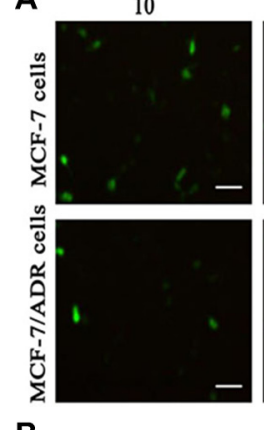

$\mathbf{B}_{90}$

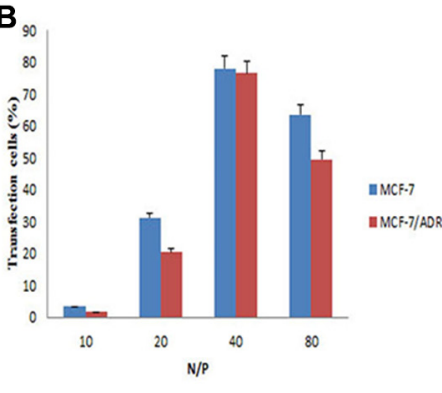

20
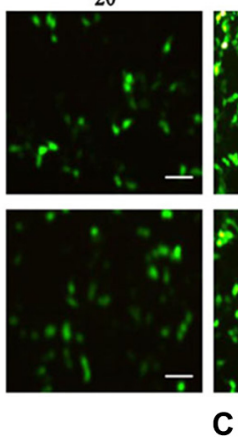

Figure 4: In vitro transfection efficiency in MCF-7 cells and MCF-7/ADR cells after treated with LHRss/pEGFP for 48 h. (A) Microscopic images of MCF-7 cells and MCF-7/ADR cells treated with LHRss/pEGFP at different N/P ratio (10, 20, 40 and 80) for $48 \mathrm{~h}$. (B) Quantitative analysis of EGFP expression in MCF-7 cells and MCF-7/ADR cells transfected with LHRss/pEGFP. (C) Flow cytometry figures display EGFP expression of MCF-7/ADR cells after treatment with LHRss/pEGFP at different N/P ratio. 
DIR was highly aggregated in the liver and lung, allowing for capture by the reticuloendothelial system (RES) [28]. Thus, the accumulation of free DIR in the tumor was quite low. LHRss/DIR accumulation at the tumor site was increased markedly, while DIR accumulation in the lung, spleen and other organs was decreased substantially. These results indicated that DIR was protected by the nanomicelle due to the enhanced permeability and retention effect [29, 30].

\section{In vivo anti-tumor effect}

The therapeutic effectiveness of LHRss/DOX/ TRAIL was evaluated in MCF-7/ADR tumor-bearing nude mice. Tumor growth in the saline group was used as a control, where the growth rate was so fast that the mean tumor volume increased from $52.1 \mathrm{~mm}^{3}$ on the first day to 2,544.6 $\mathrm{mm}^{3}$ within 21 days (Figure 7B). The similar result was also observed in BMPs-treatment group, indicating that the nanocarrier itself hardly had any physiological activity. The tumor-inhibitory capacity of LHRss/TRAIL and free DOX was $60.9 \%$ and $58.6 \%$ TIR, respectively, demonstrating that pDNA could promote tumor apoptosis in vivo. LHRss/DOX showed an increased tumor-inhibitory rate of $86.7 \%$, probably due to drug accumulation at the tumor site [33]. The most significant effect was concerned with LHRss/DOX/TRAIL, showing a tumor-inhibitory rate of $94.0 \%$. The final tumor volume was $99.2 \mathrm{~mm}^{3}$, which was only $3.9 \%$ of the tumor volume in the saline group, and 8.6-fold smaller than that in free DOX group. The predominant therapeutic effect could be triggered by targeted accumulation in the tumor, and

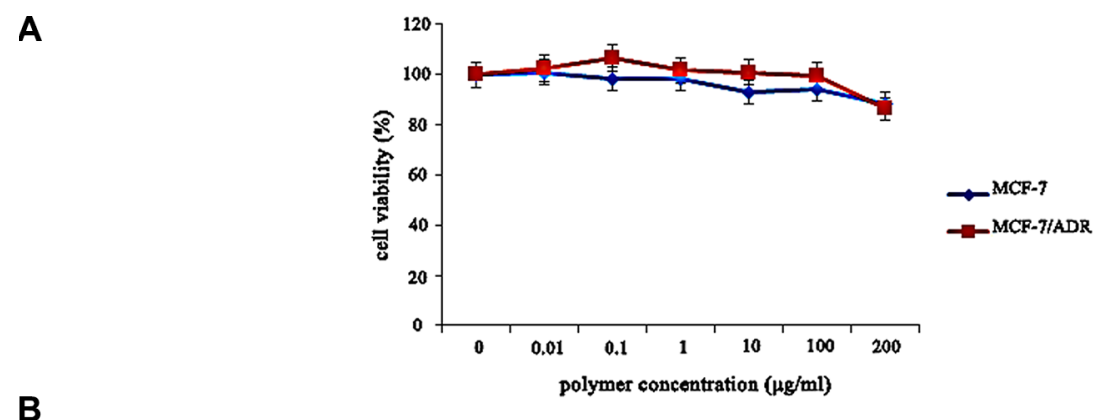

B
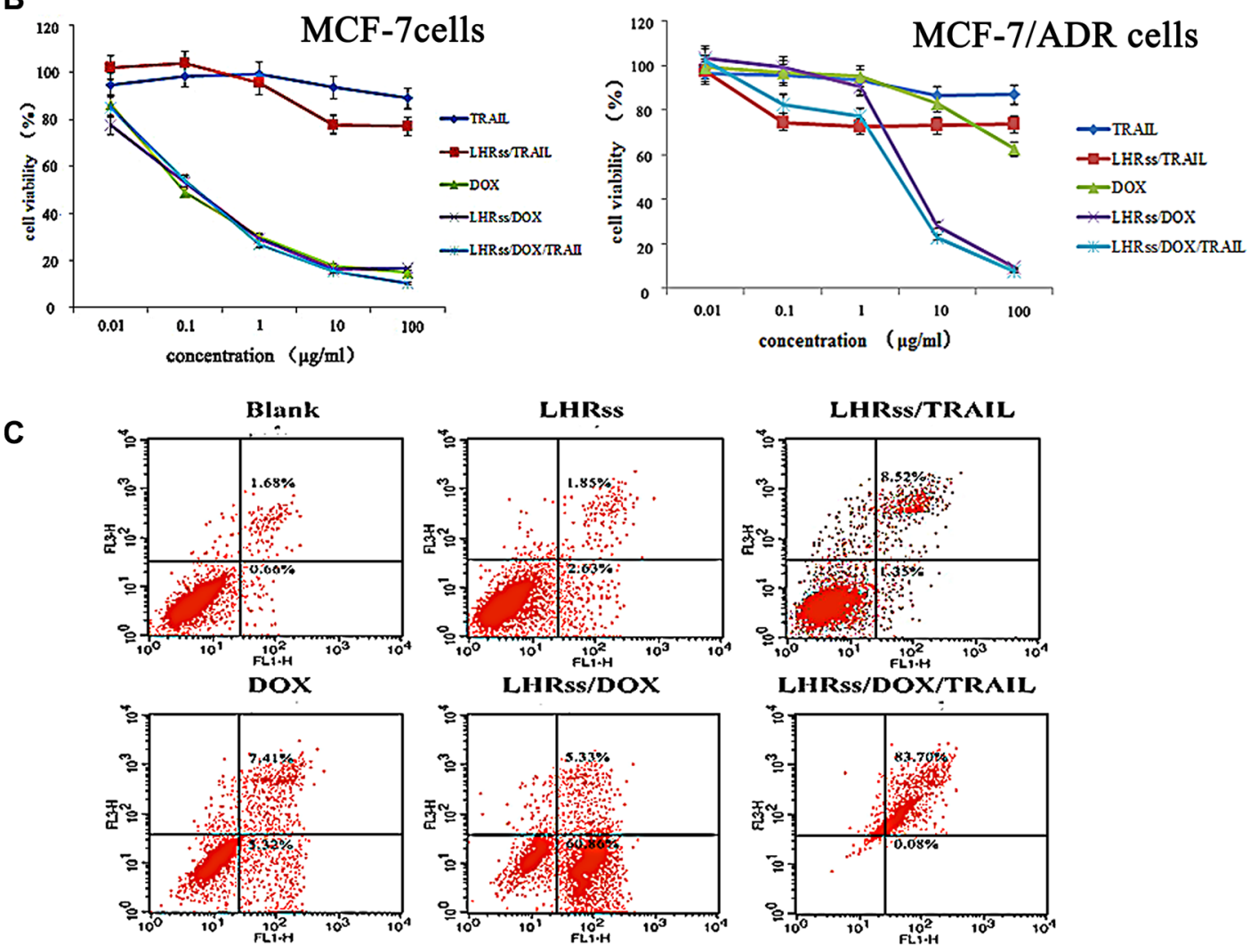

Figure 5: In vitro anti-tumor effect of LHRss/DOX/TRAIL. (A) Viability of MCF-7 cells and MCF-7/ADR cells after treatment with BMPs at different concentrations for $48 \mathrm{~h}$. (B) Viability of MCF-7 cells and MCF-7/ADR cells after treatment with TRAIL, LHRss/ TRAIL, DOX, LHRss/DOX and LHRss/DOX/TRAIL at different DOX concentrations for $48 \mathrm{~h}$. (C) Flow cytometry analysis for apoptosis of MCF-7/ADR cells induced by LHRss, LHRss/TRAIL, DOX, LHRss/DOX and LHRss/DOX/TRAIL. 

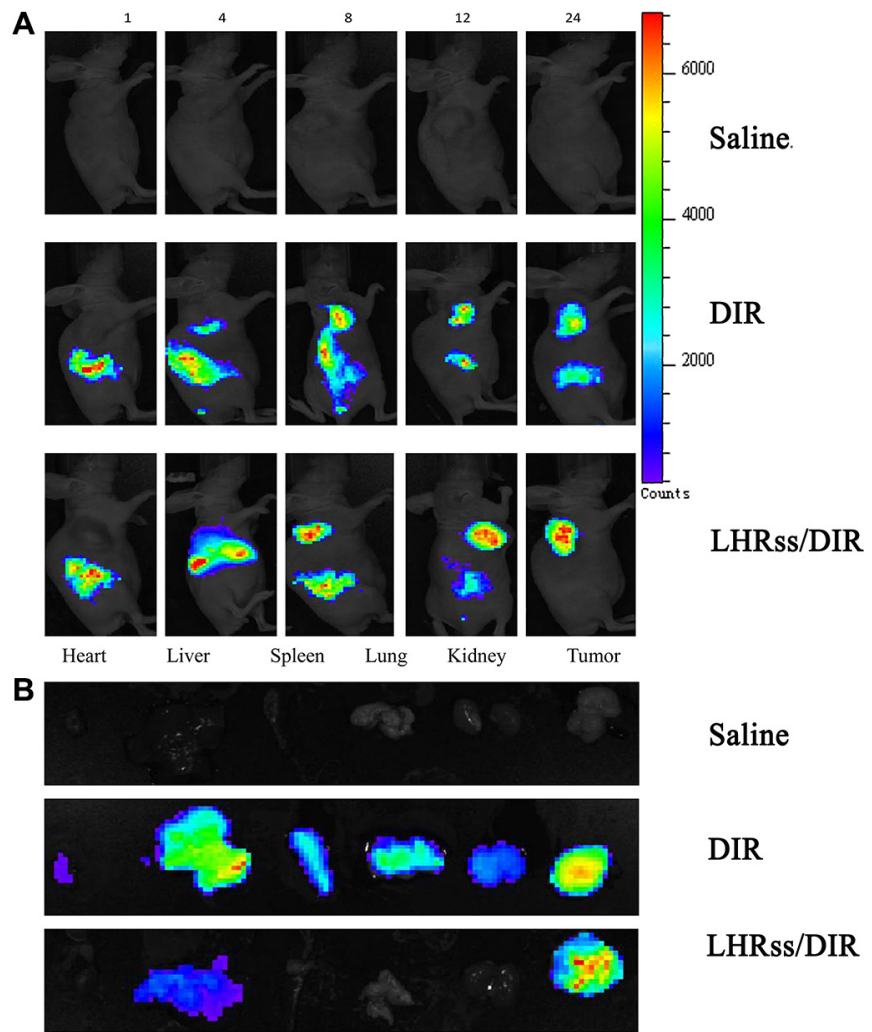

Saline

DIR

LHRss/DIR

Figure 6: Biodistribution of LHRss/DIR. (A) Biodistribution of DIR in MCF-7/ADR tumor-bearing mice at 1, 4, 8, 12 and $24 \mathrm{~h}$ after intravenous administration of DIR and LHRss/DIR at the dose of $5 \mathrm{mg} / \mathrm{kg}$. (B) Ex vivo fluorescence images of tissue including heart, liver, spleen, lung, kidneys, and tumor at $24 \mathrm{~h}$ after intravenous administration of saline, DIR and LHRss/DIR.

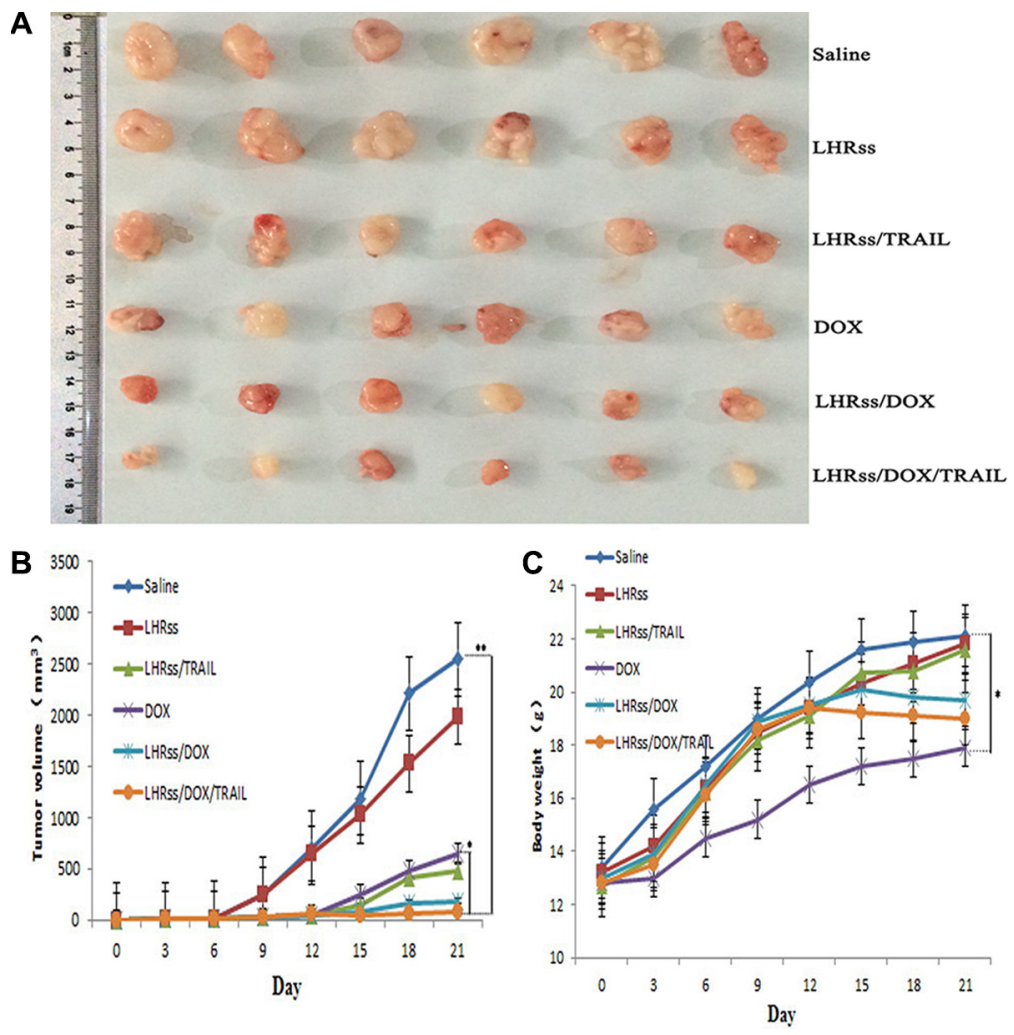

Figure 7: In vivo anti-tumor effect. (A) The picture of the tumors on day 21. (B) The tumor inhibiting rate at day 21. (C) Body weights of tumor-bearing mice. Date was given as mean $\pm \mathrm{SD}(n=6)$. $(* * p<0.01)$. 
the combination with TRAIL promoted apoptosis, which enhanced the sensitivity of tumor cells to chemotherapy $[31,32]$.

Body weight change was used an indicator of systemic toxicity (Figure 7C) [34, 35]. Importantly, mice treated with BMPs and LHRss/TRAIL had similar body weight to the saline group, indicating that the nanocarrier had nearly no systemic toxicity. Remarkably, the LHRss/ DOX and LHRss/DOX/TRAIL groups had reduced body weight after 15-day treatment, which can be explained by a loss in tumor weight. In contrast, the body weight of free DOX group was decreased substantially, indicating a severe adverse effect. Histological analysis using HE staining showed that treatment with LHRss/DOX/TRAIL resulted in extensive necrosis of the tumor tissue with little damage to the heart. However, free DOX caused significant heart necrosis but little tumor necrosis. In addition, free DOX even led to myocardial atrophy (Figure 8).

\section{CONCLUSIONS}

In this study, we designed and developed a co-delivery system of DOX and pTRAIL based on LHRss. Due to the intermolecular disulfide bond of lipoic

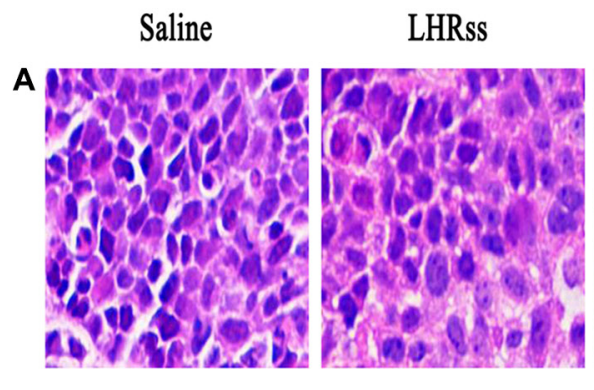

LHRss/TRAIL

DOX

LHRss/DOX

LHRss/DOX/TRAIL
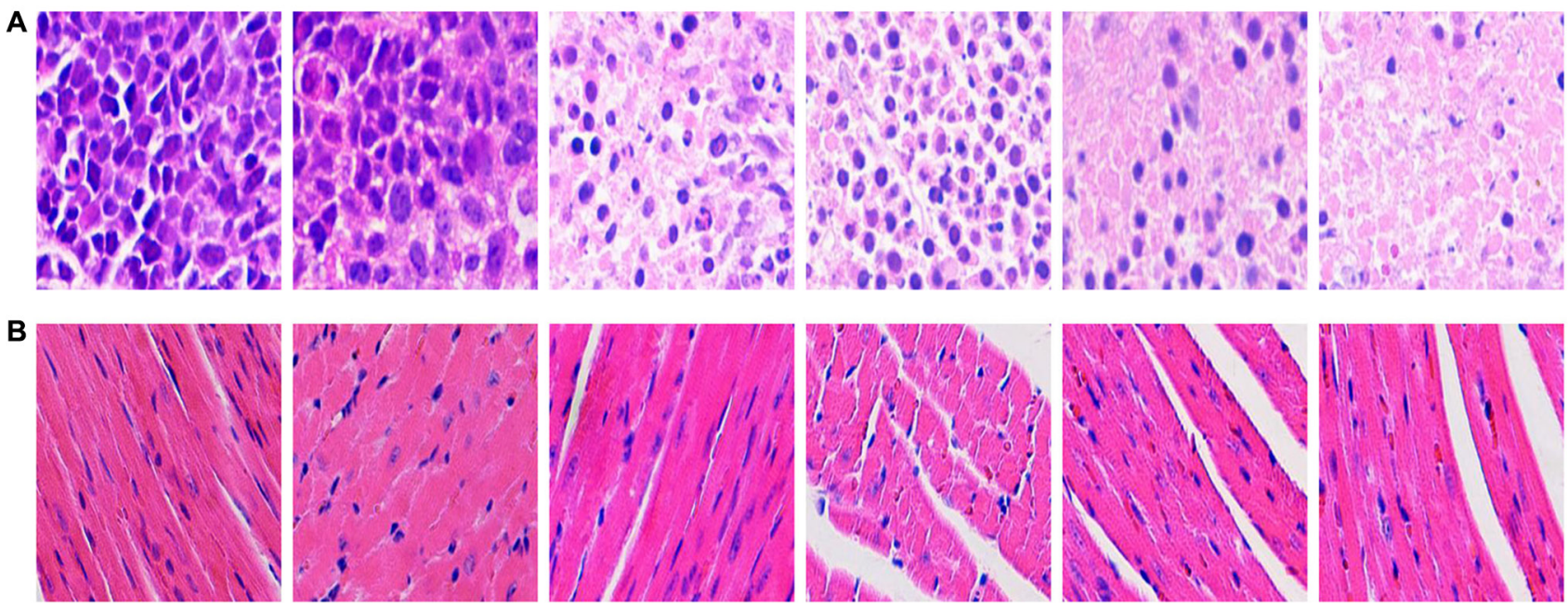

Figure 8: The histological characteristic of MCF-7/ADR tumor tissue and organ histology. (A) The histological characteristic of MCF-7/ADR tumor tissue after treatment with saline, LHRss, LHRss/TRAIL, DOX, LHRss/DOX, and LHRss/DOX/TRAIL. (B) Representative organ histology of saline, LHRss, LHRss/TRAIL, DOX, LHRss/DOX, and LHRss/DOX/TRAIL injected mice.

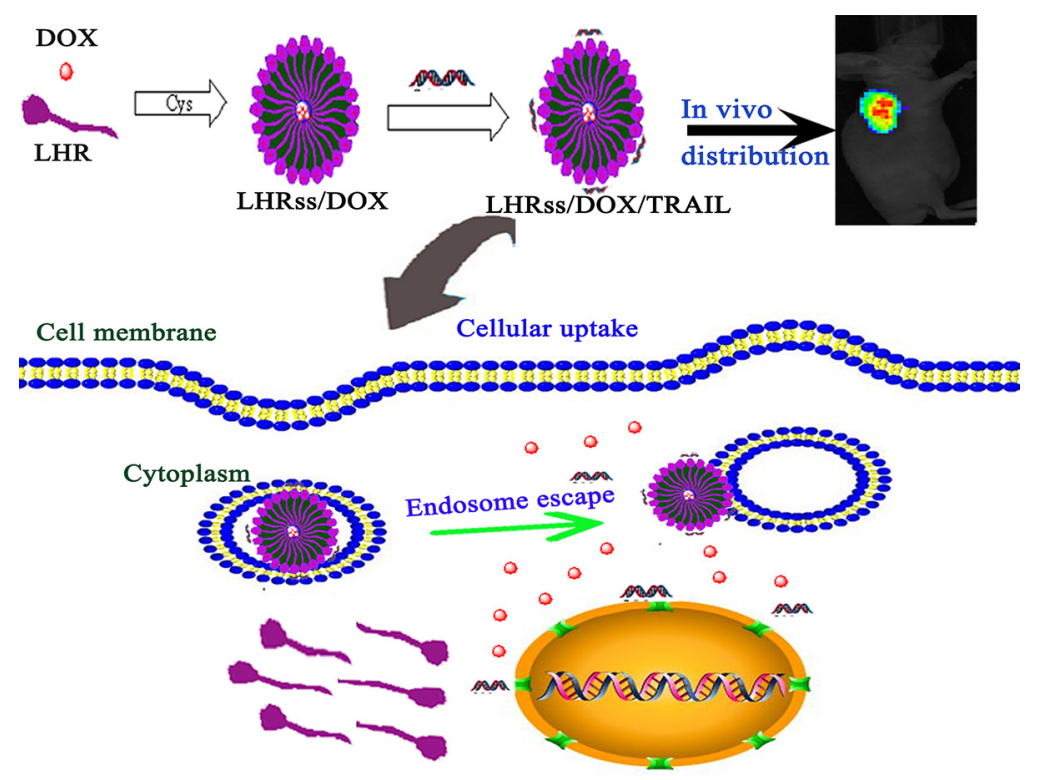

Figure 9: Scheme 1. The formation of LHRss/DOX/TRAIL and the in vitro/in vivo effect. 
acid, the nanomicelle showed a $\mathrm{pH}$-sensitive behavior, which promoted endosomal escape. LHRss/DOX/ TRAIL enhanced the intracellular accumulation of DOX, promoted the expression of TRAIL, and promoted the apoptosis of drug-resistant breast cancer cells. Because of its good biocompatibility, biodegradation and high cytotoxicity, the co-delivery system of LHRss/DOX/ TRAIL is expected to be a promising approach for the treatment of drug-resistant breast cancer.

\section{MATERIALS AND METHODS}

\section{Materials}

L-histidine hydrochloride, L-arginine and lipoic acid were purchased from Sangon Biotech (Shanghai, China). L-cysteine hydrochloride monohydrate and dithiothreitol (DTT) were purchased from Sigma-Aldrich (St Louis, MO, USA). A luciferase assay kit was gifted from Promega (Madison, WI, USA). An enhanced bicinchoninic acid protein assay kit was purchased from Beyotime (Nanjing, China). Dulbecco's Modified Eagle' Medium (DMEM), fetal bovine serum (FBS), YOYO(Y3601) and a penicillin-streptomycin solution $(5 \mathrm{KU} / \mathrm{mL})$ were purchased from Life Technologies (Carlsbad, CA, USA). The Cell Counting Kit-8 (CCK-8) was purchased from Dojindo Molecular Technologies, Inc. (Nanjing, China). Propidium iodide (PI) and an apoptosis kit were purchased from Invitrogen (Oregon, USA). pDNA (pGL3, pEGFP and pTRAIL) was purchased from Shanghai Innovation Biotechnology Co., Ltd (Shanghai, China). Doxorubicin (DOX) hydrochloride was gifted from Hisun Pharmaceutical Co., Ltd (Zhejing, China).

\section{Cell lines and cell culture}

The human breast adenocarcinoma MCF-7 cell line was obtained from the American Type Culture Collection (ATCC, Manassas, VA) and grown in DMEM supplemented with $10 \%$ FBS and antibiotics $(100 \mathrm{U} / \mathrm{mL}$ penicillin and streptomycin). The DOX-resistant cell line (MCF-7/ADR cells) was purchased from Gefan Biotech, Co., Ltd (Shanghai, China) and cultured in complete DMEM with $1 \mu \mathrm{g} / \mathrm{mL}$ DOX. Both cell lines were maintained at $37^{\circ} \mathrm{C}$ in a humidified $5 \% \mathrm{CO}_{2}$ atmosphere.

\section{Animals}

Male BALB/c nude mice (12-14 g) were purchased from the Department of Experimental Animals of the Second Military Medical University (Shanghai, China). All animal procedures were performed under the guidelines approved by the Institutional Animal Care and Use Committee (IACUC) of the Shanghai Institute of Materia Medica of the Chinese Academy of Sciences.

\section{Synthesis and characterization of polymers}

First, a histidine-arginine peptide $\left(\mathrm{H}_{3} \mathrm{R}_{6}, \mathrm{HR}\right)$ was synthesized using the method of F-moc-solid phase peptide synthesis (SPPS). Second, lipoic acid was coupled to the N-terminus of the HR peptide to obtain lipoic acid HR (LHR) using the same synthesis method. The products were purified by reverse HPLC. Then, the LHR (10 mg) was dissolved in $1 \mathrm{~mL}$ methanol, and a methanol solution of L-cysteine hydrochloride was added to the mixture under stirring to serve as a cross-linked catalyst at room temperature for $12 \mathrm{~h}$. Finally, the solvent was removed by $\mathrm{N}_{2}$ drying, and the remaining cysteine was neutralized with $\mathrm{NaOH}$. The solution was then lyophilized to obtain LHRss (Figure 1A). The molecular weight of LHR and LHRss was determined by HLC-8220 gel permeation chromatography (TOSOH Corporation, Tokyo, Japan). The synthesized polymers were also characterized by ${ }^{1} \mathrm{H}-\mathrm{NMR}$ at $600 \mathrm{MHz}$ (Varian Inc., Palo Alto, CA, USA) in deuterium oxide.

\section{Preparation and characterization of LHRss/DOX/TRAIL micelle}

\section{Co-delivery of pDNA and DOX by LHRss}

pGL3 was used as a model plasmid. For the DOXentrapped LHRss (LHRss/DOX), $2 \mathrm{mg}$ DOX.HCl was dissolved in $1 \mathrm{~mL}$ acetonitrile, and $5 \mu \mathrm{l}$ trimethylamine was added to the solution to transform $\mathrm{DOX} \cdot \mathrm{HCl}$ into hydrophobic DOX. Then, the DOX solution and sodium cholate hydrate $(1 \%)$ were placed into the LHRss solution. The organic solution was then mixed with $20 \mathrm{~mL}$ distilled water and vigorously ultrasonicated. The solvent was evaporated by vigorous stirring at 1,000 rpm overnight to remove the acetonitrile. The resulting nanomicelle suspension was centrifuged at 10,000 rpm for $15 \mathrm{~min}$. The supernatant then was passed through a $0.220 \mu \mathrm{m}$ syringe filter to eliminate the polymer and DOX aggregates. The LHRss/(DOX/pDNA) was prepared by mixing the pDNA solution $(20 \mu \mathrm{M})$ with a specified amount of the LHRss/DOX solution, and the mixture was incubated at room temperature for $30 \mathrm{~min}$ to electrostatically bind the negative pDNA to the positive surface of the nanocarrier. All procedures were carried out in the dark.

\section{Size and zeta potential of the complex}

pGL3 was used as a model plasmid. The LHRss/ DOX complex was mixed with pGL3 at different N/P ratios in $1 \mathrm{~mL}$ PBS (19 mM, pH 7.4), and the mixture was incubated at room temperature for $30 \mathrm{~min}$. Then, the particle size and zeta potential of the complex were further determined using dynamic light scattering (Zetasizer Nano ZS90, Malvern Instruments, Malvern, USA). The morphology of the LHRss/pGL3 complex at an N/P 
ratio of 40 was examined under a transmission electron microscope (Hitachi, Tokyo, Japan) at an acceleration voltage of $75 \mathrm{kV}$.

\section{Drug loading efficiency and drug release}

The loading efficiency of DOX within the nanocarrier was measured using a GloMax-Multi Jr Single Tube Multimode Reader (Promega). Briefly, $5 \mathrm{mg}$ nanocarrier was dissolved in $1 \mathrm{ml}$ PBS ( $\mathrm{pH}$ 7.4) using vigorous vortexing. This solution was transferred to a $200-\mu 1$ capillary tube. The measurement was performed in triplicate. For the determination of the drug loading content (DLC) and the drug loading efficiency (DLE), lyophilized drug-loaded nanoparticles were dissolved in DMSO. The amount of DOX was determined using fluorescence measurements. The DLC and DLE were calculated according to the following formulas:

DLC $\left(w t^{0} \%\right)=(w t$ of loaded drug/total wt of polymer and loaded drug $) \times 100 \%$

DLE $(\%)=($ weight of loaded drug/weight of drug in feed) $\times 100 \%$

The $\mathrm{pH}$-dependence of the drug release behavior of the DOX-LHRss nanocarrier was shown using a GloMaxMulti Jr Single Tube Multimode Reader. To examine the $\mathrm{pH}$-dependent dye release, DOX-loaded nanocarrier solutions $(10 \%)$ were treated with solutions of disodium hydrogen phosphate citrate buffer at different $\mathrm{pHs}$ ( $\mathrm{pH} 5.5$ and 7.4). The amount of DOX released at each time point was determined by fluorescence detector analysis.

\section{Agarose gel electrophoresis}

The condensation ability of the complexes was determined by agarose gel electrophoresis. The complexes were prepared at different N/P ratios (0.25-15). After they were incubated for $30 \mathrm{~min}$, the complexes, which included $1 \mu \mathrm{g}$ pGL3, were added to the pores of an acetic acidEDTA buffer and TAE-containing 1\% agarose gel. The gel was run at $100 \mathrm{~V}$ for $30 \mathrm{~min}$. The nucleic acid framework was irradiated under UV.

The DNA release ability was evaluated by salt separation. Complexes with an N/P ratio of 20 were prepared and incubated in $25 \mathrm{nM}$ DTT at $37^{\circ} \mathrm{C}$ for $2 \mathrm{~h}$. Samples were analyzed with agarose gel electrophoresis under the same conditions.

\section{Cellular uptake of YOYO-1-DNA and intracellular accumulation of DOX}

The DNA uptake by MCF-7 cells and MCF-7/ADR cells was analyzed using flow cytometry. MCF-7 cells and MCF-7/ADR cells were seeded into 12-well plates at $2 \times 10^{5}$ cells per well and incubated for $24 \mathrm{~h}$. After replacing the culture medium, the LHRss/YOYO-1pDNA or with the DOX solution and the LHRss/DOX were added to the MCF-7 and MCF-7/ADR cells, with a final YOYO-1pDNA concentration of $75 \mathrm{nM}$, and a final DOX concentration of $5 \mu \mathrm{g} / \mathrm{mL}$. After they were incubated for 1 , 2 , and $4 \mathrm{~h}$, the cells were washed, trypsinized, centrifuged, and re-suspended in $300 \mu \mathrm{l}$ PBS. The cells were analyzed on a FACScan flow cytometer (Becton Dickinson, San Jose, CA, USA).

\section{CLSM observation}

MCF-7 cells and MCF-7/ADR cells were seeded into glass-bottom 24-well plates at a density of $1 \times 10^{5}$ cells per well and incubated for $24 \mathrm{~h}$. After replacing the culture medium, the LHRss/ YOYO-1pDNA with or without free DOX solution, LHRss/DOX, or LHRss/ DOX/YOYO-1pDNA were added to MCF-7 cells and MCF-7/ADR cells with a final YOYO-1pDNA concentration of $75 \mathrm{nM}$ and a final DOX concentration of $5 \mu \mathrm{g} / \mathrm{mL}$. After incubation for 1, 2, and $4 \mathrm{~h}$, the medium was replaced, and the culture was expanded. At different times after transfection, the cells were fixed using 4\% paraformaldehyde and treated with 4,6-diamidino-2phenylinole dihydrochloride to stain the nucleus. Then, the cells were washed, sealed with mounting medium, and imaged using a CLSM.

\section{Gene transfection assay}

The in vitro gene transfection efficacy of the LHRss/ DNA complexes was evaluated using MCF-7 cells and MCF-7/ADR cells. pEGFP was used as the reporter gene to compare the transfection efficiency of the LHRss-based gene carrier. Transfection experiments were performed using 24-well plates. MCF-7 cells and MCF-7/ADR cells were seeded into 24 -well plates at $2 \times 10^{5}$ cells per well and incubated for $24 \mathrm{~h}$. Before transfection, the serumfree medium was replaced. Complexes including $1 \mu \mathrm{g}$ pDNA ( $p E G F P$ ) were placed into each plate with different $\mathrm{N} / \mathrm{P}$ ratios. After 4-h incubation, the culture medium was replaced with $10 \%$ FBS. For pEGFP transfection, the gene expression was detected by fluorescence microscopy (Leica, Germany). The expression of EGFP was analyzed by flow cytometry. Forty-eight hours after transfection, the cells were digested and suspended in $300 \mu \mathrm{l}$ PBS. The fluorescence intensity was detected by flow cytometry (BD, USA).

\section{Cytotoxicity assay}

To evaluate the cytotoxicity of LHRss, a CCK-8 assay was performed. Briefly, MCF-7 and MCF/ADR cells were seeded at a density of $1 \times 10^{4}$ cells per well in 96-well plates for $24 \mathrm{~h}$. The medium was then replaced with fresh culture medium containing various concentrations of the polymer. Cells without treatment were used as the control. The final concentrations of the 
polymer ranged from $1 \times 10^{-5}-2 \times 10^{-1} \mathrm{mg} / \mathrm{mL}$. After $24 \mathrm{~h}$ incubation, fresh medium containing a $10 \% \mathrm{CCK}$ 8 solution was added. The absorbance of each well was measured at $450 \mathrm{~nm}$ using a microplate reader (Thermo Fisher Scientific, Waltham, MA, USA). The absorbance of the untreated cells was set at $100 \%$, and the cell viability was expressed as the percentage relative to the absorbance of the untreated cells.

The cytotoxicity of the polymers for MCF-7 cells and MCF-7/ADR cells was evaluated with a CCK-8 assay. MCF-7 cells and MCF-7/ADR cells were inoculated into 96 well-plates with densities of $8 \times 10^{3}$ cells per well and incubated for $24 \mathrm{~h}$. Then, different concentrations of DOX, LHRss/DOX, LHRss/TRAIL and LHRss/ DOX/TRAIL were added to each well. After 24-h incubation, fresh medium containing a $10 \%$ CCK- 8 solution was added. The absorbance of each well was measured at $450 \mathrm{~nm}$ using a microplate reader (Thermo Fisher Scientific, Waltham, MA, USA). The absorbance of the untreated cells was set at $100 \%$, and cell viability was expressed as the percentage relative to the absorbance of the untreated cells. The experiment was repeated three times.

\section{Cell apoptosis}

To determine the effect of LHRss/DOX/TRAIL on cell apoptosis, MCF-7/ADR cells seeded in 12-well plates $\left(3 \times 10^{5}\right.$ cells/well $)$ were treated with LHRss, DOX, LHRss/TRAIL, LHRss/DOX, and LHRss/ TRAIL/DOX ( $5 \mu \mathrm{g} / \mathrm{mL}$ DOX and $1 \mu \mathrm{g} / \mathrm{mL}$ TRAIL) for 48 h. Cells without treatment were used as control. For the quantitative measurement of apoptosis, cells were harvested, washed twice with ice-cold PBS and then stained with Annexin V-FITC and PI for $15 \mathrm{~min}$ at room temperature in the dark. The apoptosis was analyzed by flow cytometry.

\section{Biodistribution and in vivo anti-tumor effect}

A subcutaneous tumor model was generated by injection of $1 \times 10^{6} \mathrm{MCF}-7 / \mathrm{ADR}$ cells into the right axilla of nude mice. The tumors were allowed to grow to approximately $100 \mathrm{~mm}^{3}$ before the experiment. To determine the tissue distribution of DOX and TRAIL, DIR, a lipophilic fluorescent dye was used as the model drug for the targeted research of nanomicelles. Female nude mice bearing MCF-7/ADR breast cancer were randomly assigned to 3 groups $(n=3)$ and injected with PBS, DIR, LHRss/DIR (DIR of $50 \mu \mathrm{g} / \mathrm{kg}$ ) through the tail vein. The mice were sacrificed $24 \mathrm{~h}$ later to excise the heart, liver, spleen, lung, kidney and the tumor. The excise organs and tumor were washed with cold saline and imaged using the FX Pro in vivo imaging system (Carestream Health, USA).

An in vivo anti-tumor effect assay was carried out as follows: mice bearing visible MCF-7/ADR tumors were randomly divided into saline, LHRss, LHRss/TRAIL, DOX, LHRss/DOX, and LHRss/DOX/TRAIL groups ( $n=6$ each group). The mice were intravenously administered the respective formulation once per week at a dose of $6 \mathrm{mg} / \mathrm{kg}$ DOX and $2 \mathrm{mg} / \mathrm{kg}$ TRAIL. The body weight and tumor volumes ([major axis] $\times$ [minor axis] $2 / 2$, measured by calipers) were monitored and recorded twice per week over a period of 21 days. Then, the mice were sacrificed, and their tumors were excised, weighed and photographed. The tumor inhibitory rate (TIR) was calculated using the following equation:

$\mathrm{TIR}=(1-$ Wtest $/$ Wsaline $) \times 100 \%$

Where $\mathrm{W}$ test is the mean tumor weight of the tested groups, and Wsaline refers to the mean tumor weight of the saline group.

\section{Statistical analysis}

All values are presented as the mean \pm S.D. Each value is the mean of at least three repetitive experiments in each group. The statistical significance was determined using Student's $t$-test. The differences were considered significant for $* p<0.05$ and very significant for $* * p<0.01$.

\section{ACKNOWLEDGMENTS AND FUNDING}

This study was supported by the National Natural Science Foundation of China (Nos. 81172514, 81372762).

\section{CONFLICTS OF INTEREST}

The authors declare no competing financial interest.

\section{REFERENCES}

1. Aller SG, Yu J, Ward A, Weng Y, Chittaboina S, Zhuo R, Harrell PM, Trinh YT, Zhang Q, Urbatsch IL, Chang G. Structure of P-glycoprotein reveals a molecular basis for poly-specific drug binding. Science. 2009; 323:1718-1722.

2. Ambudkar SV, Kimchi-Sarfaty C, Sauna ZE, Gottesman MM. P-glycoprotein: from genomics to mechanism. Oncogene. 2003; 22:7468-7485.

3. Johnstone RW, Ruefli AA, Lowe SW. Apoptosis: a link between cancer genetics and chemotherapy. Cell. 2002; 108 :153-164.

4. Johnstone RW, Frew AJ, Smyth MJ. The TRAIL apoptotic pathway in cancer onset, progression and therapy. Nat Rev Cancer. 2008; 8:782-798.

5. Yagita H, Takeda K, Hayakawa Y, Smyth MJ, Okumura K. TRAIL and its receptors as targets for cancer therapy. Cancer Sci. 2004; 95:777-783.

6. Wang Y, Gao S, Ye WH, Yoon HS, Yang YY. Co-delivery of drugs and DNA from cationic core-shell nanoparticles self-assembled from a biodegradable copolymer. Nat Mater. 2006; 5:791-796. 
7. Wang H, Zhao Y, Wu Y, Hu YL, Nan K, Nie G, Chen H. Enhanced anti-tumor efficacy by co-delivery of doxorubicin and paclitaxel with amphiphilic methoxy PEG-PLGA copolymer nanoparticles. Biomaterials. 2001; 32:8281-8290.

8. Farokhzad OC, Langer R. Impact of nanotechnology on drug delivery. ACS Nano. 2009; 3:16-20.

9. Kesharwani P, Gajbhiye V, Jain NK. A review of nanocarriers for the delivery of small interfering RNA. Biomaterials. 2012; 33:7138-7150.

10. Guo S, Huang L. Nanoparticles escaping RES and endosome: challenges for siRNA delivery for cancer therapy. J Nanomater. 2011; 2011:16247-16256.

11. Balazs AC, Emrick T, Russell TP. Nanoparticle polymer composites: where two small worlds meet. Science. 2006; 314:1107-1110.

12. Zhang C, Tang N, Liu X, Liang W, Xu W, Torchilin VP. siRNA-containing liposomes modified with polyarginine effectively silence the targeted gene. J Control Release. 2006; 112:229-239.

13. Zhao ZX, Gao SY, Wang JC, Chen CJ, Zhao EY, Hou WJ, Feng Q, Gao LY, Liu XY, Zhang LR, Zhang Q. Selfassembly nanomicelles based on cationic mPEG-PLAb-Polyarginine ( $\mathrm{R}$ 15) triblock copolymer for siRNA delivery. Biomaterials. 2012; 33:6793-6807.

14. Wu H, Zhu L, Torchilin V P. pH-sensitive poly (histidine)PEG/DSPE-PEG co-polymer micelles for cytosolic drug delivery. Biomaterials. 2013; 34:1213-1222.

15. Hu J, Miura S, Na K, Bae Y H. pH-responsive and charge shielded cationic micelle of poly (L-histidine)-block-short branched PEI for acidic cancer treatment. J Control Release. 2013; 172: 69-76.

16. Zhong Y, Zhang J, Cheng R, Deng C, Meng F, Xie F, Zhong Z. Reversibly crosslinked hyaluronic acid nanoparticles for active targeting and intelligent delivery of doxorubicin to drug resistant CD44+ human breast tumor xenografts. J Control Release. 2015; 205: 144-154.

17. Xu X, Jian Y, Li Y, Zhang X, Tu Z, Gu Z. Bio-inspired supramolecular hybrid dendrimers self-assembled from lowgeneration peptide dendrons for highly efficient gene delivery and biological tracking. ACS Nano. 2014; 8:9255-9264.

18. Cheng R, Feng F, Meng F, Deng C, Feijen J, Zhong Z. Glutathione-responsive nano-vehicles as a promising platform for targeted intracellular drug and gene delivery. J Control Release. 2011; 152:2-12.

19. Kim TI, Ou M, Lee M, Kim SW. Arginine-grafted bioreducible poly(disulfide amine) for gene delivery systems. Biomaterials. 2009; 30:658-664.

20. Cicchillo RM, Booker SJ. Mechanistic investigations of lipoic acid biosynthesis in Escherichia coli: both sulfur atoms in lipoic acid are contributed by the same lipoyl synthase polypeptide. J Am Chem Soc. 2005; 127:2860-2861.

21. Kirkham M, Parton RG. Clathrin-independent endocytosis: new insights into caveolae and non-caveolar lipid raft carriers. BBA-Mol Cell Res. 2005; 1745:273-286.
22. Ohnishi T, Tamai I, Sakanaka K, Sakata A, Yamashima T, Yamashita J, Tsuji A. In vivo and in vitro evidence for ATP-dependency of P-glycoprotein-mediated efflux of doxorubicin at the blood-brain barrier. Biochem Pharmacol. 1995; 49:1541-1544.

23. Tai Z, Wang X, Tian J, Gao Y, Zhang L, Yao C, Wu X, Zhang W, Zhu Q, Gao S. Biodegradable Stearylated Peptide with Internal Disulfide Bonds for Efficient Delivery of siRNA In Vitro and In Vivo. Biomacromolecules. 2015; 16:1119-1130.

24. Wen Y, Guo Z, Du Z, Fang R, Wu H, Zeng X, Wang C, Feng M, Pan S. Serum tolerance and endosomal escape capacity of histidine-modified pDNA-loaded complexes based on polyamidoamine dendrimer derivatives. Biomaterials. 2012; 33:8111-8121.

25. Mann A, Shukla V, Khanduri R, Dabral S, Singh H, Ganguli M. Linear short histidine and cysteine modified arginine peptides constitute a potential class of DNA delivery agents. Mol Pharm. 2014; 11:683-696.

26. Schädlich A, Hoffmann S, Mueller T, Caysa H, Rose C, Göpferich A, Li J, Kuntsche J, Mäder K. Accumulation of nanocarriers in the ovary: A neglected toxicity risk? J Control release. 2012; 160:105-112.

27. Texier I, Goutayer M, Da Silva A, Guyon L, Djaker N, Josserand V, Neumann E, Bibette J, Vinet F. Cyanineloaded lipid nanoparticles for improved in vivo fluorescence imaging. J Biomed Opt. 2009; 14:054005.

28. Ali I, Salim K, A Rather M, A Wani W, Haque A. Advances in nano drugs for cancer chemotherapy. Curr Cancer Drug Tar. 2011; 11:135-146.

29. Maeda H, Wu J, Sawa T, Matsumura Y, Hori K. Tumor vascular permeability and the EPR effect in macromolecular therapeutics: a review. J Control release. 2000; 65:271-284.

30. Ferrari M. Nanovector therapeutics. Curr Opin Chem Biol. 2005; 9:343-346.

31. Bae YH, Park K. Targeted drug delivery to tumors: myths, reality and possibility. J Control Release. 2011; 153:198-205.

32. Keane MM, Ettenberg SA, Nau MM, Russell EK, Lipkowitz S. Chemotherapy augments TRAIL-induced apoptosis in breast cell lines. Cancer Res. 1999; 59:734-741.

33. Guo L, Fan L, Pang Z, Ren J, Ren Y, Li J, Chen J, Wen X, Jiang X. TRAIL and doxorubicin combination enhances anti-glioblastoma effect based on passive tumor targeting of liposomes. J Control Release. 2011; 154:93-102.

34. Kedmi R, Ben-Arie N, Peer D. The systemic toxicity of positively charged lipid nanoparticles and the role of Tolllike receptor 4 in immune activation. Biomaterials. 2010; 31:6867-6875.

35. Lee ES, Na K, Bae YH. Doxorubicin loaded pH-sensitive polymeric micelles for reversal of resistant MCF-7 tumor. J Control Release. 2005; 103:405-418. 